\title{
The PRC Contract Law and Its Unique Notion of Subrogation
}

\author{
Dr Grace Li \\ Faculty of Law, \\ University of Technology, Sydney (UTS) \\ Australia \\ Grace.li@uts.edu.au
}

\begin{abstract}
This paper briefly introduces a recent history of the development of the Chinese contract law. It then analyses various specific contract law issues including formation of the contract, liability for breach of contract and the notion of subrogation. This paper finds that PRC's contract law presents a hybrid version with key concepts from both Common law tradition and the Civil law tradition. This hybrid is however unique in the way of enforcing contracting parties' rights/obligations in many contract matters. Unfortunately, without a proper case recording system in the jurisdiction, the unique Chinese legal method is somehow difficult to solve complex contract issues. This paper then argues further that there is a need to update the current system in the law of contract, particular in dealing with the right of subrogation.
\end{abstract}

\section{Introduction}

The notion of subrogation has been developed and utilised in the area of contract law in the continental European countries for centuries. It is however not that widely used in the Common Law countries. The usage of subrogation in the Common law countries is basically limited in the insurance claim cases.

China, Chinese economy and PRC's legal system have started to be noticed by the world in the recent years, especially after China's entry into WTO in 2001, which makes a big event for the world economy. With the astronomical population and infinite domestic market, China started to show its charm in the global arena of the market-economy countries. Thus, there is no doubts that the study of PRC's legal system becomes crucial to understand and deal with this country.

Since the famous 'open door policy' was announced in the late 1970s, PRC has been witnessed in the past years with reforms happened in every comer of the country including bureaucracy, education, legal system, economy and even public's mindset(Jiang, 2002). These reforms have brought enormous changes to the country. More importantly, as one consequence of these reforms, Chinese legal system has adopted many features from both Common Law countries and the traditional Civil law countries. This massive adoption process in a comparatively short period of time has created an unique hybrid legal culture in China. Unfortunately, as a fundamental element and a crucial safeguard of trading, Chinese law and legal system has been criticized heavily due to its famous framework approach and ambiguity (W. Wang, 2007). The PRC's contract law is such an example. Although the law of contract is traditionally an area of law with some hardly avoidable uncertainties, unlike other legal areas in which state interests are more heavily involved and legal rules are more settled and certain, such as family relations, property and torts (Beale, 1909), the "China brand” (M. Zhang, 2006 ) contract law has been paying negative contributions to the trading with people from other countries.

Against this background, this paper will briefly introduce a recent history of the development of the Chinese contract law to set a context of discussion. It will then analyse various specific elements of the Chinese contract law, in particular, formation of the contract, liability for breach of contract and the notion of subrogation. This paper finds that PRC's contract law presents a hybrid version with key concepts from both Common law tradition and the Civil law tradition. This hybrid is however unique in the way of enforcing contracting parties' rights/obligations in PRC's jurisdiction. Unfortunately, without a proper case law recording system, the unique Chinese legal method is somehow difficult in solving complex contract issues. This paper then further argues that there is a need to update the current system in the law of contract, particular in dealing with the right of subrogation.

\section{Context of the discussion - A brief history of Chinese Contract Law}

As a trading nation for centuries, China did not have any specific laws governing the area of contract until 1981 when the first piece of legislation passed by the National People's Congress naming the Economic Contract Law of PRC (ECL). Before that, there were only a few regulations and ordinances made by the government, which seemed running the country's economy sufficiently during a period of time, when the country's economy was planned strictly by the government. The planned economy did not promote equal entities in trade and commerce, 
the supply and demand were all strictly decided by the government; and the entire economy was self-reliance and there was no necessity to have establish law during that period of time (M. Zhang, 2006 ).

With the development of the nation, especially the changing culture in trade, the lack of specialised laws in the area of contract started to show its inconvenience and complications, which required a more operable and clearer instruction from the legislature. Against this background, in 1981, the National People's Congress passed the Economic Contracts Law of PRC. Moreover, two other important Laws were made consequently to govern some special contracts such as contracts with foreign interests and technology transaction contracts. The two laws were the Law of the PRC on Economic Contracts Involving Foreign Interests and the Law of the PRC on Technology Contracts.

The purpose of the Law of the PRC on Economic Contracts Involving Foreign Interests was to promote foreign trade and investment. It therefore drawn upon some "Western notions of freedom of contract and party autonomy.”(Potter, 1992) Moreover, it specified that international treaties and practices were applicable to matters not covered by Chinese law, with the exception of PRC reservation. 1 However, at the meantime, the other two PRC contract related laws still retained many socialist vestiges, such as the sanctity of State ownership and the instrumental view of law.(F. Chen, 2001)

Development of domestic economy and the international trend of globalization required China to open up its market further and to provide some more sensible laws in the area of contract. Other elements were adding the necessity such as the inconsistency among these three pieces legislation as well as the overlapping contents. Responding to these problems, a decision was made by the State Council to do a substantial reform of the law governs the area of contract. As the achievement of this initiative, in 1999, the PRC enacted the Uniform Contract Law (UCL). The UCL was passed for the purpose of "protecting the legitimate rights and interests of the parties to contracts, maintaining the socio-economic order and promoting the socialist modernization."2 It was believed that this promulgation of the UCL was especially important to China at the time because of China's then desire to join the World Trade Organization (WTO) (F. Chen, 2001). This new law also invalidated of those three laws simultaneously.3

Generally speaking, The UCL gives parties more freedom and flexibility in their contractual relations than existed prior to this enactment (Hitchingham, 2000). It also demonstrated the China's willingness to open its legal system to foreign influences and to receive inspirations from foreign laws. 4

To provide a comprehensive understanding of this law and its implications to trading with China, some specific features of this piece of legislation were discussed in next part of this paper by comparing with the law of contract in the Common law tradition as well as UNIDROIT 2004.

\section{The PRC Contract Law and its implications to trade}

Structurally, the UCL is divided into three parts - General Provisions, Specific Provisions and Supplementary Provisions - with 23 Chapters featuring 428 Articles. The first part - General Provisions - has 8 Chapters: General Provisions; Conclusion of Contracts; Effectiveness of Contracts; Performance of Contracts; Modification and Assignment of Contracts; Termination of the Rights and Obligations of Contracts; Liability for Breach of Contracts; Miscellaneous Provisions. The second part - Specific Provisions - contains 15 Chapters dealing with 15 types of contract: Sales; Supply and Use of Electricity, Water, Gas or Heating; Donation; Loans; Lease; Financial Lease; Hired Works; Construction Projects; Transport; Technology; Storage; Warehousing; Mandate; Commission Agency; Intermediation. The Supplementary Provisions contain one Article on the effectiveness of the new Contract Law and provides for the abrogation of the three former Contract Laws.

In drafting the new Contract Law, the Chinese legislators referred extensively to the UNIDROIT Principles of International Commercial Contracts.5 Many Articles of the UCL, in particular those in the chapter on General Provisions, are similar in nature to the UNIDROIT Principles in Contract Law. Moreover, as mentioned above, the UCL also includes a set of specific provisions, which aims to provide a more practical guideline to the contract issues in specific areas.

\footnotetext{
${ }^{1}$ Article 142, the Law of the PRC on Economic Contracts Involving Foreign Interests

${ }^{2}$ UCL, art. 1 (PRC).

${ }^{3}$ UCL, art. 428 (PRC).

${ }^{4}$ Accordingly, UCL was firstly drafted by scholars familiar with the Civil Law system and then was amended by scholars from Common Law study background, many international conventions was heavily referred to as well, which was to maximise the capacity of this contract law to the vast cases coming from the commercial reality. The legal principles that Chinese legislators referred to including the Principles of International Commercial Contracts drafted by the International Institute for the Unification of Private Law (UNIDROIT Principles), the United Nations Convention for the International Sale of Goods (CISG), and other foreign legal standards. See for example, James C. Hitchingham, Stepping Up to the Needs of the International Market Place: An Analysis of the 1999 "Uniform" Contract Law of the People's Republic of China, 1 AsianPacific Law \& Policy Journal 8: 4 (2000).

${ }^{5}$ Here is the previous version of UNIDROIT, which was published in 1994.
} 
Despite the similarities, many features of UCL are still alien for practitioners from other jurisdictions. In practice, there are still many other issues that can either complicate the use of this legislation or, even frustrate the overall process of seeking fair and justice in the country. Four specific aspects are therefore selected and examined below to provide a snapshot of these (unfamiliar) features, focusing on the contract issue and its implications to trading with China.

\subsection{Sources of modern PRC contract law - where to find the laws}

The sources of modern contract law in China includes the UCL, Chinese Civil Code, a serial of judicial interpretations handed down by the PRC Supreme court and an important special sources, which is named by this paper 'hidden' sources. The hidden sources are not the sources 'hiding' anywhere; they are the sources unclear and hard to find in practice, such as different levels of administrative regulations, rules, ordinances and guidelines. Interestingly, the hidden sources are, sometimes, very important and powerful 'laws' in dealing with individual cases.

The various sources are explained further below. Given the fact that UCL is to be discussed separately in the next part, it is not included here.

\subsubsection{PRC Civil Code}

Starting from the Chinese Civil code, which is a comprehensive code, governs every comer of people's daily life in the country. Being only a small part of this code, contract related provisions are covered by 6 clauses6. These clauses are very general in nature and, in many occasions, even difficult to understand.

For example, clause 113 in the Civil Code provides "If both parties breach the contract, each party shall bear its respective civil liability.” Clause like this is of principle in nature. It neither provides any details on how the responsibilities can be defined in the breach, nor the method of calculation of liabilities suppose to be allocated respectively. They are therefore serving a mere purpose of showing the lawmaker's attitude towards the issue of breach of contract. Another example would be the clause 115, which provides 'a party's right to claim compensation for losses shall not be affected by the alteration or termination of a contract'. This clause is easy to create confusion in practice. In the situation where contract is terminated for a lawful purpose such as force majore, surely, party's right to claim compensation would be affected. The same principle applies when the contract is altered with the consents of both parties.

Thus, generally speaking, when dispute arises in any given contract in the country, one would not possibly be able to rely on the Civil Code to solve the matter. The Civil Code is there, as it states in its clause 4, to 'provide the principles of voluntariness, fairness, making compensation for equal value, honesty and credibility’.

\subsubsection{The Doctrine of Precedent}

Despite the fact that precedent is the most important source of the contract law in the Common law legal tradition and it is also an essential aid in solving international trade disputes under UNIDROIT International Commercial Contracts, precedent does not play an important role in the Chinese contract law system at all. In PRC, not all court decisions or cases are published and available to the public. In fact, the large majority remains unavailable (X. Wang, 2007). Although the Supreme People's Court, and the Standing Committee of the National People's Congress will occasionally make interpretations of various laws in which ambiguities are at issue, or clarification is deemed necessary by the Communist Party leadership, they are much less common than one would expect of courts in Common Law jurisdictions or international forums would provide.

There are reasons that the significance of precedent is not well taken in China. Understanding of these reasons can be helpful to a better understanding of Chinese contract law and its implications to trade. Some of the main reasons are discussed below.

Firstly of all, the judicial independence is traditionally a big problem in China. It is worth mentioning that judgments and the publishing of cases are highly political processes, and the courts are normally lack the necessary autonomy to render unbiased decisions that might conflict with Communist Party policy, values, or current laws (Farewell, 2006). Sometimes a case will be chosen to be published in order to make a point, or set an example for the public to build confidence in the judicial system. Other times, cases will be published to demonstrate the "rule of Law" to people from other jurisdictions, or to set forth new policies regarding foreign investment, or the activities of foreigners in China. In this sense, publishing UCL in year 1999 as a supporting measure for China's consequent WTO entry provides a good example. It is also well know that the government of China exerts strong pressure on the courts in cases to which they believe there is a national policy interest at stake, or to which they believe are politically sensitive. In addition, despite China's recent revisions of criminal law,

\footnotetext{
${ }^{6}$ Article 111-116, PRC Civil Code
} 
criminal procedure, civil law, and civil procedure, often trials are closed, conducted days after charges are filed, or even months or years later. Lawyers have been known to have been kept from their clients, or even kept from attending such politically sensitive trials altogether. Intimidation is also known to play a role, and many lawyers are unwilling to take on clients involved in trials considered sensitive, in order to protect their legal careers (Matheson, 2006). Thus, when practitioner from a Common law jurisdiction faces a dispute in China where he or she might want to cite a precedent (surely, there are precedents), the practicality of doing it is slim both on the likelihood of finding the proper authority and on accessibility in the litigation process even it is a case from an official source such as PRC supreme court case note database.

Secondly, it also deserves a mention that cases in China play an important role as a tool of the Ministry of Propaganda, not only in their decisions as to what gets published, but more importantly, as to what does not get published. Nonetheless, we feel it is important to publish here, some of the cases that the Chinese government feels the domestic and international communities should have access to. We know that they all covey some message to the public at large, however subtle it may be. The messages are always there as a result of a legal system without checks and balances, which is often used as a "tool" to convey messages or enforce a policy, rather than implement blind justice (Matheson, 2006).

Another unfortunate feature of Chinese case law is its infantile recording system. From the author's personal experience, it is interesting to browse one of the most popular case note databases, in fact, the only official case note database in China www.chinacourt.org7, which is set up by PRC Supreme Court. As people who can read both Chinese and English, the first interesting feature is the vast differences between the Chinese version and English version of this site. Many functions and information available on the Chinese site are not seen on the English site, which include the important case law database, anti corruption forum, free posting sections for website visitors and many current news. This situation can be caused due to a slow process of setting up English version for various sections; it can also be caused by unrevealed political reasons. As an experiment, the author of this paper tried to search within 'Civil litigation' database with any case with the word 'contract' in its title. The result of this search returned 3951 cases with a latest case in 2006 and oldest case in 20018. Unfortunately, many of these cases appeared in the result list neither have a clear date of trail and a clear court reasoning.9 Most of these case notes read more like newspaper stories rather than serious court cases.10 It is also interesting noting that photos of the parties in court hearing and/or in other scenarios have been published with many emotional in many of these cases in the database.11 Nevertheless, all these clearly show that the case recording system in China is at its very infancy stage, which is due to both the traditionally under-recognized value of the case law approach and perhaps the lack of political wills This situation reinforces the fact that different method should be adopted in solving trading issues involving contract matter when use Chinese contract law. The standard Western method of citing authorities (cases of statutes) and arguing the matter based on the authorities does not seemed to be the best way in China. Instead, as will be discussed in the particulars of the UCL, preparing an argument based on framework/principle of law rather than focusing on the application of law (previous cases) is recommended.

Lastly, one of the reasons that precedent does not hold great weight in litigation is due to the questionable qualification of Chinese judges. The Communist Party in China took office in 1945, which signified the establishment of a 'New PRC'. However, its judicial system had not been properly developed until 1978, when the Cultural Revolution finished (Mei, Fu, \& Xu, 2002). Numerous reforms and restructurings of judicial system have been conducted by the State Government in the past decades, which achieved significantly in establishing the Country's court system (Tong, 2007). At the same time, the qualification of Chinese judges has been improved to a large degree. Unfortunately, in general, Chinese judges, as one special group of people in the country, is still not comparable to the judges in the Western countries in terms of the way of training judge, years of experiences before becoming a judge, skills of reason a judgment, the number of qualified judges and even the familiarity with the laws (A. Wu, 2007). This situation has created many uncertainties for people who are not familiar with the Chinese system (even for PRC practitioner sometimes), which is something that one needs to bear in mind in trading with the nation, at least in the near future where there is no sign of significant changes.

\footnotetext{
${ }^{7}$ English version website is http://en.chinacourt.org/index.php

${ }^{8}$ The trial was conducted while writing this paper on 16 May 2008.

${ }^{9}$ An example of case without trail date can be found from http://www.chinacourt.org/public/detail.php?id=300823\&k_title=合同\&k_content=合同\&k_author=

${ }^{10}$ Examples of newspaper story like case note are very commonly from this official case law database. For example, http://www.chinacourt.org/public/detail.php?id=301499\&k_title=合同\&k_content=合同\&k_author=

${ }^{11}$ An example of these cases can be found from

http://www.chinacourt.org/public/detail.php?id=301669\&k_title=合同\&k_content=合同\&k_author=
} 


\subsubsection{Hidden Contract Laws}

Apart from the sources above, there are many "hidden laws" functioning at the same time. The reason to call them "hidden laws", as explained, is because these are something which unlikely or very difficult to be found without a great deal of research as well as a high level of familiarity with the Chinese legal and political system. However, these hidden laws are sometimes very powerful in dealing with individual cases.

In a simple term, these laws are 'hiding' in two different places. One is in other legislations or statute in the country and the other is in the vast administrative regulations, rules and ordinance and so on. There are many examples of this kind. For instance, the law of the PRC on Chinese-foreign Equity Joint Ventures (2001) is one of them, in which, many provisions are contract related.12 As to the administrative part, policies, rules, regulations and ordinances from different levels of government are always referred in litigation as a major source of the law. Given the fact that there are more than 30 provincial level governments, hundreds of city councils and thousands of local councils, the volume of regulations and ordinances are considerable. Many of the contract related regulations could be found in this system. Sources of this kind are normally available in Chinese version only and rarely published in the place other then its local jurisdiction. Interestingly, these 'so-called laws' can be very powerful in dealing with the individual cases. For example, if a dispute arises regarding a manufacturing contract signed between a foreigner and a local Chinese provider in an administrative district, in Zhengzhou city, which is the capital of HeNan province in China. To solve the dispute, the court will need to look at the ordinance published by the authority in the district level, city level, provincial level and national level. Moreover, depending on the nature of the business, the court may also need to look at the laws in other areas such as foreign investment.( $\mathrm{Li}, 2007)$ Therefore, it is fair to say that the task of finding the hidden laws would be a 'mission impossible' for most foreigners, not to mention the big number of conflicts13 among these laws (L. Wang, 2008).

Thus, as practitioner who is not quite familiar with the system and not sure where to find the law, the task can be enormous. The best way is to get as much information as one can from the counter party of the contract at the contract drafting stage. Of course, seeking independent advice from local practitioners is absolutely crucial. Comparing with the Western way of doing a comprehensive research before signing a contract, in China, getting to know the people who know the law is much more important then getting to know the law by yourself. In the situation where a different point or conflicts in law or regulation is detected, which can be often, take the regulation or law made by a higher level of administrative body or decision-making authority.

\subsection{The legislation - what the law looks like}

UCL comprises of two main types of provisions, namely "the General Provisions" and "the Specific Provisions" 14. The general provisions provide some contract essentials, including formation of the contract, contract effectiveness, performance, modification and termination etc. These essentials are applicable to all the contracts.15 Comparing with the general provisions, the specific provision is a list of specific types of contract, such as contract for sales of good, contract for donation, contract for financial leasing and construction contract etc.16

Reading the provisions while acknowledging the particular cultural, political and economic situation, one would be dazzled by the familiarity of most of the black-letter-rules, but one would be also amazed by some of the unexpected surprises that the law may provide. For example, Article 11 explicitly mentions that e-mails not only as a tool for contract conclusion, but also as a proof of writing. And, it has rules on the liability for misusing confidential information obtained during pre-contractual negotiations, Art. 43 UCL.(X. Wang, 2003)

One of the distinctive characteristics of this UCL is its significant similarity with the UNIDROIT Principles of international commercial contracts, especially the similarities between the UCL General provisions and the UNIDROIT Contract Principles. These similarities include, for example, the application of the rules, where both of these two documents chose to have a broad approach of what contract/s can be governed by the rules.

\footnotetext{
${ }^{12}$ Many contract related articles can be found in Law of the People's Republic of China on Chinese-foreign Equity Joint Ventures (2001), including article 2, 14 and 15.

${ }^{13}$ Article 14 of Law of the People's Republic of China on Chinese-foreign Equity Joint Ventures (2001) provides that 'in case of heavy losses, failure of a party to perform its obligations under the contract and the articles of association, or force majeure etc., the parties to the joint venture may terminate the contract through their consultation and agreement, subject to approval by the examination and approval authorities and to registration with the state's competent department in charge of industry and commerce administration. In cases of losses caused by a breach of contract, the financial responsibility shall be borne by the party that has breached the contract'. Article 94 of UCL provides that the parties may dissolve the contract under any of the following circumstances including, for example, force majeure, which does not need any approval by any authorities.

${ }^{14}$ Although there is the Supplementary Provision in the Act, this paper is not discussing it because its insignificance of containing one Article only on the effectiveness of the new Contract Law and provides for the abrogation of the three former Contract Laws.

${ }^{15}$ The general provisions in UCL are from article 1 to article 129.

${ }^{16}$ The specific provisions in UCL are from article 130 to article 427, which include 15 different types of specific contract.
} 
UNIDROIT Principles clearly stipulates in its Preamble that "these Principles set forth general rules for international commercial contracts."(UNIDROIT, 2004). It is further emphasised that "a broadest possible sense" should be used to understand the concept of 'commercial' contracts, therefore, its principles govern not only trade transactions for the supply or exchange of goods or services, but also other types of economic transactions such as investment and/or concession agreements, contracts for professional services and so on. (Y. Zhang \& Huang, 2001). Moreover, there are many other similar principles in these two documents. For instance, regarding to the form of contract, UNIDROIT Principles states that "nothing in these Principles requires a contract, statement or any other act to be made in or evidenced by a particular form. It may be proved by any means, including witnesses."17 A similar provision can be found in UCL article 10, which provides 'the parties may conclude a contract in written, oral or other forms' and Article 11, further provides '"Written form" as used herein means any form which renders the information contained in a contract capable of being reproduced in tangible form such as a written agreement, a letter, or electronic text (including telegram, telex, facsimile, electronic data interchange and e-mail)'. Considering the fact that 'written contract' was the only recognised form of contract under the old PRC contract law system (before UCL 1999), there were no doubts that the UCL had make a big advancement regarding the recognised forms of contract, which is also consistent with the old Common Law tradition that oral contract is a possible form of contract. (Cusumano, Wiseman, \& Christensen, 1996). Therefore, it is fair to say that this advancement definitely made UCL system linking with the International practices more closely.

Another interesting feature exists commonly between UCL and UNIDROIT Principles, which is the 'offer and acceptance rule'. This rule specifics that 'a contract may be concluded either by the acceptance of an offer or by conduct of the parties that is sufficient to show agreement'18 and/or 'the parties shall, in making a contract, take the form of offer and acceptance'19. It is clear that under these two documents, offer and acceptance makes a valid contract in most of the cases. More importantly, this rule is also similar with the formation provision in the United Nations Convention on Contracts for the International Sale of Goods (CISG), in which, art. 23 provides 'A contract is concluded at the moment when an acceptance of an offer becomes effective in accordance with the provisions of this Convention'. (UNIDROIT, 1980). Thus, this paper takes a courageous assumption that the international trading system and its relevant rules has been aiming at simplifying and standardising the contract formation and its terms. Situation is, however, very different in the common law tradition, in which, any valid contract will need to have an essential element of 'consideration' (Cusumano et al., 1996). Not to comment on which is a more effective approach in practice, as a mere advice for practitioners familiar with the Common law system, arguing for the consideration issue of contract formation would be unwise and unnecessary when handling the conflicts involving Chinese contract law. would be:

Responding to the question posed in the heading of this section - what the law looks like, a simple answer

- The PRC contract law system looks messy, it appears everywhere and was mainly included in the UCL;

- With the simple language and straightforward provisions, the UCL is a reader friendly legislation and does not contain many legal jargons;

- The law is set out in a way very similar way with other international rules in commercial contract such as the UNIDROIT Principles and the CISG; and

- It also features some limited Common Law based principles such as party’s autonomy.

\subsection{Particulars of the UCL - what do you need to know}

\subsubsection{Formation of the contract}

Studying into the basic elements of UCL, the law requires three elements must be present in order to form a contract: the parties20, the agreement, and the object. In addition, according to Art 13 of UCL, contracts are formed according to an offer and acceptance model. An offer under the UCL is a "person's declaration of intention to conclude a contract with another person."21 This definition is very similar to many laws in other jurisdiction as well as provisions in international conventions.22

\footnotetext{
${ }^{17}$ Article 1.2 UNIDROIT Principles

18 Art. 2.1.1 UNIDROIT Principles

${ }^{19}$ Art. 13 UCL

${ }^{20}$ The word 'parties' can be found throughout the UCL, which however, does not provide any information for unilateral contract.

${ }^{21}$ Art. 14 UCL

${ }^{22}$ UNIDROIT Principles, art. 2.1 - "A contract may be concluded either by the acceptance of an offer or by conduct of the parties that is sufficient to show agreement.".
} 
As explained, the rule of consideration appears nowhere in Chinese legal system both for simple contract and for formal deed. Some people believe that the difference of consideration does not create big problem because even in Common Law jurisdictions such as a country like Australia, formal contract and deed does not need consideration as well. But, without this principle, one should be very careful with things like "an open offer", which does create complexity in practice (Matheson, 2006).

Always, in practice, things may not be as easy as it reads in the black letter law. Using the formation of the contract as an example, although it is clear that oral contract is an admissible form of contract in UCL, as a matter of fact, when use as an evidence, oral contract is more likely to be set aside by the court judges when decide on cases (Sui \& Wang, 2007). In practice, oral contract is often used (or 'misused') to describe the finalising stage of a contract negotiation, basically means an agreement is reached orally, which will be followed (in most cases) by a formal contract (in written form) to give the effectiveness of a legal instrument (Li, 2007).

\subsubsection{Liability for Breach of Contract}

In Common law, there is a concept of "a genuine pre-estimate”. If one party of the contract can prove that the amount agreed on the contract represents a genuine pre-estimate of the loss likely to be incurred as a result of not being able to perform the contractual responsibilities, then that amount will be used by the court as the basis for assessing the loss and so the damages. For court to adopt this approach, party has to prove it is a "genuine preestimate" and it then will be for the court to examine the amount payable and to determine its nature.(Cusumano et al., 1996).

In comparison, Art.114 of UCL provides that 'the parties may stipulate that in case of breach of contract by either party a certain amount of penalty shall be paid to the other party according to the seriousness of the breach, and may also stipulate the method for calculating the sum of compensation for losses caused by the breach of contract', which is very different with the Common law principle that has been used by the courts for centuries.

Once more, this paper is not to comment on which is a better approach, merely, this would be a matter that the Common law lawyers need to be very careful about when they draft contract with PRC parties. For example, when draft a contract provision relating to the breach of contract and the amount of remedies/penalty, it would be beneficial to set out a clear amount under certain type of breach. If exact amount is difficult to specify at the stage of drafting, parties should consider to set out a method of calculation or at least a rough way of deciding the amount such as a percentage of the entire contract amount or each of the installment. Although the court can sometime reduce the specified amount of penalty by using its discretion, the possibility of this kind is not high. Same as to the increase, although Art. 114 provides a mechanism that party can get the set amount increased23, the likelihood of getting this increase is slim as well. It is wise in practice to get the amount right early in the drafting stage and clearly stated in the contract.

\subsubsection{Privity of the contract vs. the notion of subrogation}

The doctrine of privity in contract law provides that a contract cannot confer rights or impose obligations arising under it on any person or agent except the parties to it (Cusumano et al., 1996). This seems to make perfect sense only parties to contracts should be able to sue to enforce their rights or claim damages as such. However, the UCL provides the contrary. Art. 73 in UCL specifies that 'if a debtor is indolent in exercising its matured creditor's rights and thus causes losses to the creditor, the creditor may apply to a people's court to subrogate the debtor's creditor's rights and exercise them under the creditor's name, except for the creditor's rights exclusively belonging to the debtor'. In other words, the term 'subrogation' gives right to a person who is not a party of a given contract to claim rights against the contracting party. For example, in the situation where party A owns party B 100 dollars, party B owns party C 100 dollars, and both debts are due. If party B is tardy in exercising it due creditor's right and refuse to pay 100 dollars to party $C$ by saying he does not have money, party $C$ would be in the position to sue A for the due 100 dollars on B's behalf. The notion of subrogation was adopted from many other authorities in the Continental European counties, such as in France Civil Code24, Spanish Civil Code25 and Italian Civil Code26, Japanese Civil Code27 also provides a similar notion, interesting to note that there is no such notion in the German legal system, which is where a dominating part of the PRC laws were originally adopted from (Snow, 2008).

When studying the law of subrogation, there are many common features between the traditional Civil Law and the Chinese approach, which mainly include the conditions of using the right of subrogation, the

\footnotetext{
${ }^{23}$ According to the Para 2, art. 114 of UCL , 'If the stipulated penalty for breach of contract is lower than the loss caused by the breach, the party concerned may apply to a people's court or an arbitration institution for an increase.'

${ }^{24}$ Art 1686

${ }^{25}$ Art. 1111

${ }^{26}$ Art. 1234

${ }^{27}$ Art. 432
} 
objective and approach of perusing this right. There are also unique characters of the Chinese approach in contract issues. This paper summarises them as below:

- Difference 1: The consequence of using this right of subrogation. Provisions in UCL and its related consequent Judicial Interpretation (1999)28, show that the method of perusing the right of subrogation is (in China) for the "semi-creditor/3rd party29" to claim a debt to a contracting party in a direct way. This "semi-creditor/3rd party", in the situation with a successful claim, enjoys the result directly before return the access amount to the creditor (if there is access amount). Whereas in the Civil Law tradition, the "semi-creditor/3rd party" can only claim the debt on behalf of the real creditor - the real creditor is normally the contracting party. With the successful claim, the real creditor will enjoy the result and will need to pay the payable debt plus any relevant costs to the "semi-creditor/3rd party", which is similar with the agency relationship.

- Difference 2: The method of using this right. UCL and its related consequent Judicial Interpretation (1999) specify that the right of subrogation can only be conducted with court order. Whereas in the Civil law tradition, it can be done privately for the due debts.

Thus, to provide a better understanding for people who are not familiar with the subrogation principle, it is worthwhile to summarize and compare the advantages and disadvantages of this notion in the PRC's contract rules.

Advantages: There are advantages of having this provision in the contract law. First of all, this principle can be of incentive for semi-creditor to claim his or her due debt. Secondly, Chinese believe that this principle breaks a judicial black point where an enforcement is not possible for 3rd party (Y. J. Chen, 2000). It enables the 3rd party to make a claim by using his or her own name, which further enables the People's Court to possibly freeze the account or withdraw the fund from the party at fault. Lastly, adopting of this principle leads to cost saving in transactions. The fact that the 3rd party enjoys the successful claim before the real creditor makes the transaction easier, comparing with the traditional approach where the 3rd party claims, creditor enjoys and pays 3rd party.

Disadvantages: China might be the only jurisdiction where the 3rd party can enjoy the claim before the real creditor, which can cause problems. Thinking of situation where there are more than one semi-creditors/3rd parties to one real creditor (the contracting party), if all the semi-creditors/3rd parties peruse their subrogation right, there will be major priority issue and fairness issue. In addition, there is only silence when the contract laws touch upon the situation of sharing of the successful claim among all the semi-creditors/3rd parties. Moreover, there has been no judicial interpretation regarding this issue (sharing the successful claim) yet. This paper therefore argues that the disadvantage overweight the advantages of this Chinese subrogation principle with the fact that there are not enough jurisprudence and authorities from domestic laws and overseas authorities in this point.

In conclusion, the notion of subrogation in UCL is an area to confuse the practitioners from other jurisdictions including those from the jurisdiction with the similar notion of subrogation. Although this topic has became a controversial issue for sometime, there have been no sign of removing this provision in the PRC laws.

\subsection{Judicial interpretation}

There is a common misunderstanding that in China, judicial interpretation does not have the legal binding authority. In fact, statutory interpretations made by the Supreme Court of PRC, the highest judicial body, does create binding authorities in practice (W. Wang, 2007).

In the area of contract law (after the UCL), there have been several judicial interpretations handed down from the Supreme Court or PRC. The most important one was the Interpretation of Issues relating to Contract Law of PRC 199930. It provided a more detailed instruction on understanding of the UCL.

The judicial interpretation in China comes in a similar format as the real legislation with numbered articles and provisions. For instance, the Interpretation of Issues relating to Contract Law of PRC 1999 comes with 7 chapters and 30 articles. Another example of judicial interpretation in the recent year was the Interpretation of Issues relating to the Construction Contract31, which comes with 28 articles and becomes effective from 1st Jan 2005.

However, the weight of judicial interpretation in China has traditionally been an unsettled issue. On the one hand, it is clearly stated in Article 4 of the Rules of the Supreme People's Court on the Work of Judicial

\footnotetext{
${ }^{28}$ The 1999 judicial interpretation will be discussed in detail in the later part of this paper.

${ }^{29}$ Here the 'semi-creditor $/ 3^{\text {rd }}$ party' is the party who is not in the contract.

${ }^{30}$ http://www.law-lib.com/law/law_view.asp?id=486

31 http://www.chinacourt.org/flwk/show1.php?file_id=97038
} 
Interpretation32 that judicial interpretation is of the same weight as to the legislation; on the other hand, there are no other supporting authorities, and, especially, there is no constitutional foundation for that. In fact, the PRC Constitution makes it very clear that the validity of the law can only be gained with the consent of the People's Congress33. Unfortunately, although there have been lots of debates regarding the validity and the legality of the judicial interpretations in litigation, there have been no clarification made by the authority so far (X. Wu, 2004).

Another controversial issue relating to judicial interpretation in China is the issue of "re-interpretation of the judicial interpretation" (Shan, 2007), which, as seen, has caused some huge amount of debates in practice (X. $\mathrm{Wu}, 2004)$. It basically refers to the situation where the PRC Supreme Court founds that it is necessary to clarify or revise some specific interpretations they made in the past by making new interpretations on the same or a similar issue. As one can imagine, with the unclear validity and effectiveness of the original judicial interpretation, the re-interpreted version will brings more complexity and confusion to the matter (Shan, 2007). To push this matter to another level of debate, this paper holds a view that judicial interpretation in China prepared and promulgated by the Supreme Court is, in its natural fact, illegal, or at least, unlawful. The body makes the interpretation (the PRC Supreme Court) does not have the legal authority to do so under the constitution and the very instrument makes the legal effect of the judicial interpretation, the Rules of the Supreme People's Court on the Work of Judicial Interpretation, is in conflict with the PRC Constitution, therefore, it should not be seen as a valid rule.

Unfortunately, none of these matters received any clarification from the lawmakers in the country. It has been nearly a decade since the UCL (1999) became effective. The way that PRC courts deal with the contract issues have not been consistent over the years, which have been criticized constantly and significantly (Zheng \& Xin, 2008) but have not had any signs of possible amendments to date.

\section{Conclusion}

As revealed above, as a unique figure in the international trading circle, China, Chinese law and legal system present a different picture to the Common law world, and therefore, it is challenging to utilise this system when conflict arises in trading with this nation. Moreover, as an essential piece of legislation with particular importance to trade, the PRC contract law, with its different approach in legal principles and ambiguity in many provisions adds more complexity to the matter.

While convergence between China's contract law as written, embodied primarily in the UCL, and that of Western economic and legal systems has taken place, there remain variations in both coverage and emphasis (Matheson, 2006). Moreover, it remains unclear how Chinese contract law on the books translated to the law which had been applied or enforced, that mainly because of the immaturity of the case recording system in the country. The multiplicity of judicial forums, the variation in abilities of judicial decision makers, and the predilection to resolve disputes by means other than litigation all add to the uncertainty in this area. In addition, as noted previously, although Westerners view contract formation/signing as the culmination of the process, this is just the beginning of the process for the Chinese. Similarly, the process of exploring these differences in approach that marks the current status of contracting in and with China is just beginning as well.(Matheson, 2006).

This actually leads to the very point of this paper, when doing business with China, in general, finding the law and understanding the law is important. However, because the way that Chinese laws are structured, it is not only hard to find the law but also difficult to understand them. Even when one can understand the law (doubt if it can ever happen to a non-Chinese, or even Chinese), sometimes, it is still hard to use the law in practice because of its famous ambiguous and framework/principle approach, and also because of the lack of a proper case notes supporting system. At the same time, for those who have been doing business in China for a while, would understand no doubts, there is a thing that people always use in solving problems, which is the so-called 'Guan-Xi (the connections)'. Guan-Xi can, in fact, makes the business in China prosperous or vanishing. Therefore, the last advice for utilising the PRC contract law system is, as mentioned at the beginning of this paper in the introduction part, to know the people who know what the laws are and how the laws work in their own ways.

\footnotetext{
${ }^{32}$ http://www.court.gov.cn/lawdata/explain/etc/200703230020.htm

${ }^{33}$ Article 58, Chapter 3 of PRC constitution states 'the law-making power is held by the People's Congress and the Standing Committee of the People's Congress only.'
} 


\section{Reference}

Beale, J. H. (1909). What Law Governs the Validity of a Contract. Harvard Law Review, 23(1), 1.

Chen, F. (2001). The New Era of Chinese Contract Law: History, Development and a Comparative Analysis. Journal of International Law, 27153.

Chen, Y. J. (2000). The Right of Subrogation In J. H. Zhang (Ed.), Theory of PRC Civil Code (Vol. 1, pp. 300). Beijing: China Central University of Political Science and Law.

Cong, H. (2004). Knowing the Chinese Market Economy Retrieved 1 Jan, 2006, from http://info.news.hc360.com/HTML/001/002/007/014/001/87908.htm

Cusumano, S., Wiseman, L., \& Christensen, S. (1996). Contracts. Sydney: Butterworths.

Farewell, J. (2006). The Supremacy of the Judgment in China. Journal of Asia Study, 3(1), 20.

Hitchingham, J. (2000). Stepping Up to the Needs of the International Market Place: An Analysis of the 1999 "Uniform" Contract Law of the People's Republic of China. Asian-Pacific Law \& Policy Journal, 8(1), 4

Jiang, Z. (2002). Establishing a better socialist society and exploring a new era with Chinese characteristics (No. 001). Beijing: Chinese Communist Party National Congress

Kreise, S. (2006). Convergence, Culture and Contract Law in China Minnesota Journal of International Law 15, 329.

Li, X. (2007). The Details of Winning a Case in the Complicated Regulatory Structure. ZhengZhou University Law Review, 56(4), 77.

Matheson, J. H. (2006). Convergence, Culture and Contract Law in China. Minnesota Journal of International Law, 15, 329

Mei, G., Fu, Q., \& Xu, H. (2002). Cultural Revolution and the Damages It brought to China. Asian Journal of Politics and Law, 12(1), 45.

Pattison, P., \& Herron, D. (2003). The Mountains Are High and the Emperor is Far Away: Sanctity of Contract Law in China. Business Law Journal 40, 459.

Potter, P. (1992). The Economic Contract Law of China Legitimating and Contract Autonomy in the PRC University of Washington Press, 97.

Shan, T. (2007). The War of Re-Interpret the Judicial Interpretation Business Law Review, 122(4), 23.

Snow, J. (2008). The Understanding of the Chinese Legal System. Beijing University Law Review, 134(2), 76.

Sui, H., \& Wang, D. (2007). Contract Performance and Remedies Business Law Review, 12(2), 71.

Tong, H. (2007). The Four 'Most' Features in the Decade Long Court System Reform. Review of Judicial Reform in PRC Retrieved 12 May, 2008, from http://www.jcrb.com/200711/ca656834.htm

UNIDROIT. (1980). United Nations Convention On Contracts For The International Sale Of Goods (1980) [CISG]. Retrieved. from http://www.cisg.law.pace.edu/cisg/text/treaty.html.

UNIDROIT. (2004). UNIDROIT Principles of International Commercial Contracts. Retrieved. from http://www.unidroit.org/english/principles/contracts/principles2004/blackletter2004.pdf.

Wang, L. (2008). The Political Structure of RPC and Its Implication to the Legal System. WuHan University Law Journal, 112(1), 45.

Wang, W. (2007). Choose the Right Chinese Law and the Choice of Law. Renmin University Law review, 51(1), 135.

Wang, X. (2003). Are We Closer to the Equality Through the Way of Making a Fair Contract? . Beijing University Law Journal, 242(4), 11.

Wang, X. (2007). Jurisprudence in the Modern Chinese Legal System. Wu Han: Wu Han University.

Wu, A. (2007). Improve the Qualification of Our Lawyers (No. 4). Beijing: National Lawyers Association

Wu, X. (2004). A Study of the Effect of Judicial Interpretation in Criminal Matters Retrieved 12 November, 2007, from http://www.iolaw.org.cn/showarticle.asp?id=1155

Zhang, M. (2006 ). Choice of Law in Contracts: A Chinese Approach Northwestern Journal of international law \& Business, 26, 289.

Zhang, Y., \& Huang, D. (2001). The New Contract Law in the People's Republic of China and the UNIDROIT Principles of International Commercial Contracts : A Brief Comparison. Retrieved 3 March, 2008, from http://www.unidroit.org/english/publications/review/articles/2000-3.htm

Zheng, X. H., \& Xin, X. (2008). What We Can Do and What We Cannot Do In Solving the Contract Disputes Journal Business and Law 78(1), 223. 